\section{PROF. DODEL-PORT ON THE FERTILISATION OF RED SEAWEEDS BY INFUSORIA}

I $\mathrm{N}$ a recent number of the excellent periodical Kosmos, Dr. Dodel-Port, the eminent Zurich botanist, has published the results of a series of observations made by him regarding the part played by some infusoria in the fertilisation of a certain species of red seaweeds or Floridex, viz., Polysiphonia subulata, T. Ag. The paper is of biological importance, since it forms, as far as our knowledge extends, the first record of a possible participation of animals in the fertilisation of cryptogams, which in itself seems an interesting paxallel to the relations existing between insects and phanerogams. We have pleasure, therefore, in presenting our readers with an abstract, the illustrations for which have been placed at our disposal through the kindness of the author and of the publishers of Kosmos.

In previous numbers of the same periodical Dr. Hermann Miiller had sketched the history of the evolution of the floral world and had shown upon what basis rests the entire relation between flowers and insects. This basis is the passage from a state of things in which the male cells discharged their products in a medium of water to that in which this event took place in the dry atmosphere, which transition period occurred at the upper boundary of the cryptogamic flora of prehistoric times.

In almost all cryptogams, which are not agamic, the contents of the male sexual cells are actively movable; when they leave the male cell they move freely about in the water by means of vividly oscillating cilia. They therefore possess the faculty of moving to the distant female organ, and there to complete fertilisation. In the case of phanerogams, the independent mobility of the pollencbodies has become an impossibility. To effect the anion of pollen-grains with that particular part of the female Alower which is destined to receive them, in most plants some external agent must interfere. In many cases, specially in the lower regions of the fioral world, the wind, gravitation, or both together, are the agents in question; in the majority of the higher phanerogams, insects, or occasionally other animals, undertake the conveyance of the pollen.

Now there are a great number of cryptogams, in which the contents of the male cells which are emptied into the water do not possess the faculty of independent motion, as they are not endowed with cilia, and are therefore dependent on the action of external forces for their locomotion. To these belongs the great and highly differentiated order of so-called red seaweeds or Florideæ, chiefly marine plants which vary much in form and colour, and which no one who has ever attentively observed on the sea-coast will ever forget. Their antherozoids, which are generally spherical, are discharged into the water as motionless cells, and are yielded up to the play of currents in the same way as in our anemophilous phanerogams, the pollen grains pass as a dust into the air, and are moved to and fro by the winds. There are many analogies between Florideæ and bigher phanerogams, regarding their sexual conditions. Thus, amongst the former we find many species which are diøcious, similar to the lowest phanerogams amongst gymnosperms, and to others of higher order. The chances for fertilisation in their case are therefore quite similar to those applying to dicecious phanerogams. Often the male plants grow at a considerable distance from the female plants of the same species. In the spring of I $878 \mathrm{Dr}$. DodelPort, during a series of microscopical examinations of the red seaweeds of the Adriatic, extending over four weeks, found only female and agamic (tetrasporous) specimens of Polysiphonic subulata, T. Ag., and looked in vain for male specimens, of which only at the end of his investigations he could obtain a few. Their respective localities of growth were evidently considerably apart, and yet at all times Dr. Dodel-Port found female specimens in all stages of fertilisation. The spermatozoids discharged by the male plants therefore found their way to the distant female plants in spite of their own immobility and general passive behaviour. The sea-water must therefore have frequently been in vivid motion.

These facts being ascertained, the thought easily suggested etself that possibly animals might take part in the fertilisation, particularly as there is never a want of small marine animals roaming about in the Florideæ forests, such as infusoria, crustacea, annelids, starfish, \&c. But what particularly attracted Dr. Dodel-Port's attention was the regular occurrence of innumerable bell-shaped animalcules (Vorticella) on the shrub-like branches of Polysiphonia subulata. In the course of closer investigation of the phenomena of fertilisation in the female organ, during and after the adherence of the antherozoid with the trichogyne, Dr. Dodel-Port eventually arrived at the full conviction that in the case of Polysiphonia the little Vorticellæ facilitate the conveyance of the antherozoids to the trichogyne, and that they act according to a natural law in the same way as do the pollencollecting bees when by visiting the willow-catkins they assist at their fertilisation. The investigation of the sexual conditions of Floridex is as yet in its infancy; it is to be hoped that more numerous researches in this direction will shortly be made, and possibly relations may be found to exist between other species of this order and certain animals similar to those discovered by Dr. Dodel-Port in the case of Polysiphonia and Vorticella. The details of the interesting relations in this case are shortly as follows :-

Fig. I represents the male reproductive organ (antheridium) of Polysiphonia subulata magnified 480 times. These antheridia often appear in large numbers at the upper branch.ends of the male plant, laterally close to the apex which continues its growth, at the spot where, in the vegetative state, young branches would form. In their earliest stage the antheridia consist, like the young branches, of a single row of cells. By repeated longitudinal and lateral divisions a polycellular body is soon formed, which begins with a short stem-cell $(s t)$, and which, on the side furthest away from the maternal thallus-branch, is protected by a forked hair $(g h)$.

The ripe antheridium in external appearance reminds one very strongly of a maize cone; a row of $4^{-6}$ cylindrical cells $(a, a)$ in the axis of the whole organ represent the spine of the cone, while the surface is covered over by numerous antherozoid mother-cells $(\mathrm{sm}, \mathrm{sm})$ representing the grains of maize. Before the antheridium is ripe the latter are polyhedrical, but afterwards they assume a round shape, as the drawing shows. All parts of the male organ are colourless; the antherozoid mother-cells are filled by a finely granular plasma, which is soon differentiated into a round body, which subsequentiy is discharged from the mother-cell as an antherozoid $(s, s)$. Thus within a short time the ripe antheridium discharges some $400-800$ ball-shaped antherozoids into the surrounding sea-water. The single antherozoid is a little globule of protoplasm, without cell-wall or any locomotive organ. In the centre of this globular primordial cell a strong magnifying power shows a little nodule which strongly refracts light, and round which a few smaller colourless plasma granules are grouped. As it freely floats in the water, the antherozoid is analogous to a pollen-grain of an anemophilous phanerogam.

The female reproductive organ of Polysiphonia subulata is a polycellular carpogonium of relatively high differentiation. It originates upon the female plant closely below the apex of the thallus-branches, and generally there are several of them forming successively at varying intervals from the branch-end downwards.

Fig. 2 shows the carpogonium-bearing branch-end of a female specimen of. Polysiphonia subulata. $c^{\prime} g^{\prime}$ is a very young carpogonium; $c g, c g$ are two mature ones; $t^{\prime}$ and $t^{\prime \prime}$ are two trichogynes; Vort. are two Vorticellæ. The whole is magnified 300 times.

In Fig. 3 a carpogonium $(c a)$ is represented magnified still more ( 480 times). Vort. is a Vorticella; $s, s$ are antherozoids. In the mature state the carpogonium consists of three essential parts, viz. :-

r. The basal portion $f$ (Fig. 3).

2. The fertile spore-forming part $c g$.

3. The hair apparatus $t$ and $g h$.

The basal portion consists of five tubular cells running parallel to each other, of which in Fig. 3 are seen only two. Then follows the fertile part, $c \mathrm{~g}$, which is an oval cellular body, consisting of some $20-26$ icells. A central cell, copiously filled with granular protoplasm, is surrounded by a number of irregular, peripheric cells, and awaits fertilisation, in order afterwards to transform itself into the spore-forming apparatus, while the remaining 19-25 peripheric cells become the case of the spore fruit through further divisions (see also Fig. 4, $h(h)$. The uppermost part of the female organ is the hair apparatus, which, in Polysiphonia, consists of the forked rhair, $g h$, and the trichogyne, $t$ (Fig. 3 ). The forked hair forms very early upon the young carpogonium, and indeed long before the trichogyne is formed; its position is always upon the true apex of the whole organ, although at times it stands apparently laterally from the apex. The duration of its existence and its presence at the time of fertilisation (it disappears immediately 
afterwards) prove it to be an organ of some use in that process. The most essential and important part of the hair apparatus, however, is the trichogyne ( $t$, in Figs. 2 and 3), i.e., the receptive organ, which in Florideæ has a similar signification to that of the elongated style in many phanerogams, while the central part, $c g$, of the carpogonium is the analogue of the closed

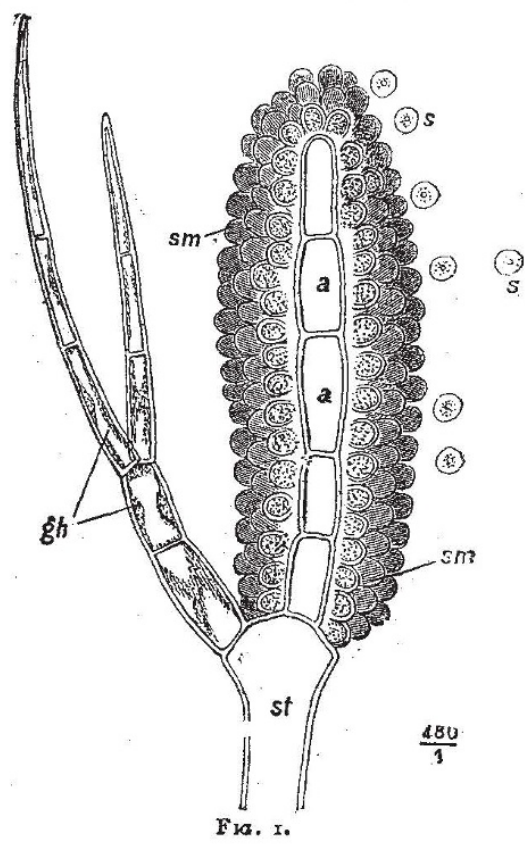

ovarium of angiosperms. The trichogyne is a slender, colourless hair, consisting of but a single cell, which rises from the carpogonium laterally from the apex of the latter, and does not quite attain the length of the forked hair, $g h$. It forms just about the time when all other parts of the carpogonium have attained that degree of differentiation which they possess during

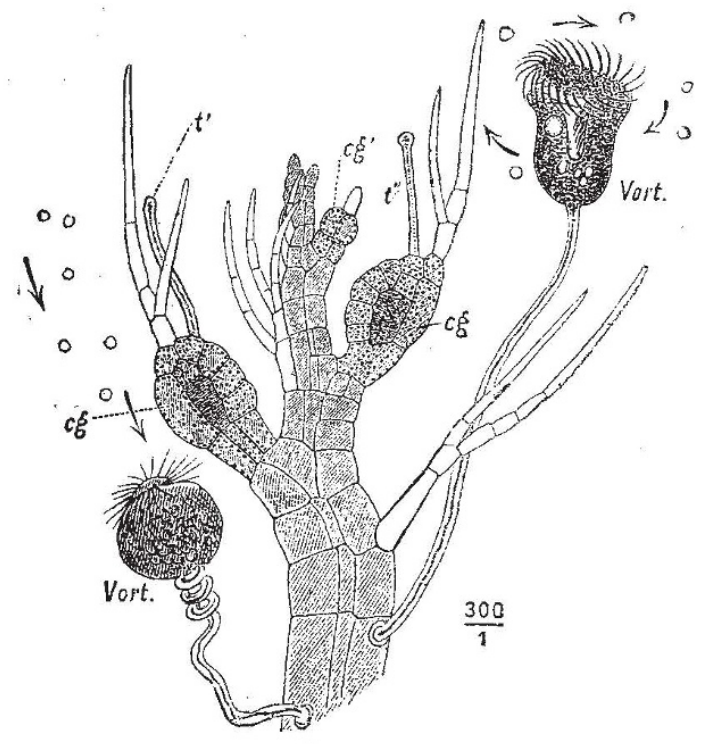

FIG. 2.

fertilisation. In the full-grown state the trichogyne is of the same thickness in its entire length, and. rounded off suddenly at the upper end. The narrow canal of the trichogyne contains colourless, finely-granular protoplasm.

Now if antherozoids of Polysiphonia subulata, which were freshly discharged by the antheridia and have been accidentally carried near by currents, come into contact with the upper part of the trichogyne, they get firmly attached to the latter. It is particularly the apex of the trichogyne which possesses the faculty of retaining s the globular antherozoids. Then the granular protoplasmic contents of the antherozoids pass into the

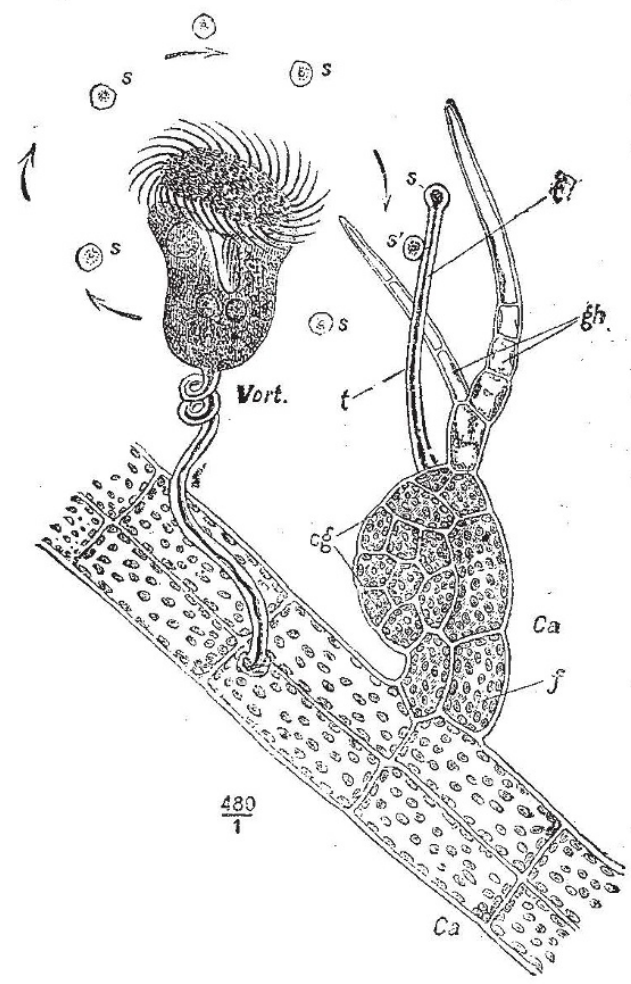

Frg. 3.

interior of the trichogyne (Fig. $3 s^{\prime \prime}$ ). A part of it descends down the trichogynic canal into the carpogonium, giving the fertilising impulse to the central cell of the carpogonium. EThis process is quite similar to the corresponding one in phanero. gams.

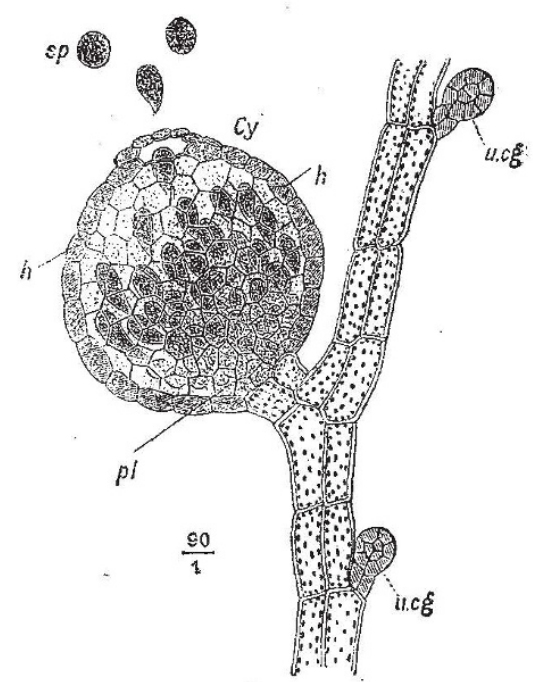

FIG. 4 .

As the antherozoids of Floridex are totally devoid of active locomotive organs, the possibility of fertilisation, $i, e_{\text {, }}$, the coming into contact of the antherozoids and the trichogyne, of course rests entirely upon a lucky chance. The antherozoids reach the female organs passively, either by the swn weight or through 
the currents of the water, caused by waves, wind, or tides, and doubtless in many cases through the incessant movements of some marine animals. The greater the distance betwreen the antheridia and the carpogonia, the smaller are, of course, the chances of fertilisation; the more violently the water is moved about in the vicinity of and between the separated organs, the more probably will the lucky accident of the union of both elements take place.

During a long series of investigations of the reproductive phenomena of Polysiphonia, Dr. Dodel-Port found regularly on the bushy thallus, and particularly upon the uppermost and youngest branches, an enormous number of the well-known stalked animalcules, Vorticellæ, which had settled there, and were, as usual, in incessant motion. Often they appeared in dozens in the field of the microscope, and, with the constant vibration of their cilia, they were very troublesome, at least up to the moment when Dr. Dodel-Port had directly observed their friendly co-operation in the fertilisation he was studying. He was a frequent witness of the process depicted in Fig. 3, where numerous antherozoids were whirled round and round in the whirl caused by a Vorticella, and where frequently antherozoids came into contact with the trichogyne, and remained attached to it (Fig. $3, s^{\prime}$ and $s^{\prime \prime}$ ) for a longer or shorter period. It was entirely due to the motion caused by Vorticellæ that Dr. Dodel-Port was enabled to follow the phenomenon of the attachment of the antherozoids to the trichogyne from beginning to end. The motions of the Vorticellæ are particularly varied through the repeated contractions of their stalks into short spirals, and thus they cause various currents in the water, by all of which the antherozoids are carried along like any other small passive body that may be suspended in the water. (Compare Fig. 2, where one of the Vorticellæ is just contracting its stalk, the arrows in each case indicating the direction of the currents.)

The presence of numerous Vorticella thus imparts to the passive antherozoids a kind of motion much resembling that of the sperm-cells of other cryptogams which are endowed with active cilia. From this follows, with mathematical certainty, that the probability of the antherozoid falling on the trichogyne in the presence of Vorticelle is immensely greater than that which would exist were there no animals present.

At the same time, it is evident that this probability is yet increased in the case of Polysiphonia subulata through the presence of the forked hair, $g h$, in the vicinity of the trichogyne, because the whirls caused by the animalcules will often be cleft by the forked hair, and thus secondary whirls will be produced. Often in Polysiphonia, carpogonia were found which were not fertilised. Thus Fig. 4 represents a ripe and spore-ejecting cystocarp, $c y$, and two carpogonia, $u c g$, which remained unfertilised. This was particularly the case on thallus-branches, which were less densely crowded with Vorticellæ- nnother, although negative, proof of Dr. Dodel-Port's theory. It is not particularly remarkable that Vorticella should inhabit Polysiphonia in large numbers, because these animalcules, as Dr. Dodel-Port observed, feed with predilection on the antherozoids of this plant. Thus we have here a condition of things similar to the relations between certain flowers and pollen-consuming insects. The consumption of antherozoids by the Vorticellæ is, of course, far too insignificant to merit any consideration, particularly if compared to the greal advantages regarding fertilisation which the presence of the animalcules brings with it. Moreover, a comparison of the male plant of Polysiphonia with a female specimen shows that here also, as in most phanerogams, thousands more male cells are formed than are necessary for fertilisation.

After fertilisation the carpogonium develops into a cystocarp, i.e., the spore-forming fruit (Fig. 4). Shortly after fertilisation the whole hair apparatus disappears. The wall-cells of the carpogonium now begin to grow quickly and to divide by membranes perpendicular to the surface. They form a cellular case (hh, Fig. 4), which has an orifice in the apex, long before the spores are ripe. In the 'meantime the central cell of the fertilised carpogonium begins to form a number of densely-packed short branches, which, as a series of cells radiating in all directions, fill the basis of the capsule-shaped fruit. The central cell is therefore called the placenta-cell. At the ends of the ramified cell-series which radiate from it, pear-shaped and dark red spores form (carpospores), which, as soon as they have attained a certain size, become detached and pass into the water through the orifice at the apex of the cystocarp. In this state they are perfectly capable of further development and soon begin to germinate.
Dr. Dodel-Port concludes his interesting treatise with the following suggestive sentences :-

"The total absence of active organs of locomotion in the antherozoids of Florideæ points to a common ancestor from which the different branches of the Floridex have inherited the immobility of the antherozoids. No doubt that during the differentiation of the red seaweeds many forms have died out in consequence of the fertilisation not taking place through the passivity of the male cells, while other forms have retired to localities which through active water-currents favour the process of fertilisation in spite of the immobility of the antherozoids. It is well known that now we find most of the present species of Florideæ on the coasts of warmer seas, which are constantly washed by the waves, while the northern coasts, which are covered by crusts of ice during a great portion of the year, are very poor in red seaweeds. Future researches will have to show how far in many of these aquatic plants the differentiation of the genera took place in the sense of an adaptation to the small marine animals which inhabit them and favour their fertilisation in the way I have pointed out. If many seaweeds in their bushy shrublike thallus harbour certain infusoria, bryozoa, hydræ, sponges, crustacea, annelids, and small starfishes, and offer to them excellent hiding-places or nourishment, so that these animals inhabit them with special predilection, then it is certainly possible that occasionally a correlation was formedior adaptation took place, which was mutually advantageous and which would find numerous analogies in the domain of the multiple cross relations between the higher flowering plants and insects. In this sense I consider it my duty to submit to the criticism of biologists a point hitherto overlooked in the biology of red seaweeds, and bearing upon the explanation of the morphological differentiation of submerged aquatic plants."

\section{THE BRITISH ASSOCIATION REPORTS}

Report of the Comimittee appointed for the Purpose of Arranging for the Occupation of a Table at the Zoological Station at Naples, the Conmittee consisting of Dr. M. Foster, Prof. Rolleston, Mr. Dezw. Smith (Secretary), Prof. Huxiey, Dr. Carpenter, Dr. Grevnn Jeffreys, Mr. Sclater, Mr. F. M. Balfour, Sir C. Wyville Thomson, and Prof. Ray Lankester. - Since we submitted our last Report to the Association, the Zoological Station at Naples has continued to be successful in providing opportunity and appliances for naturalists studying the various forms of marine animals and plants. From September I, 1878 , to the end of July, 1879, twenty-six naturalists have occupied the tables at the Institution. A list of their names and the time of stay will be found appended. During the same period, packages of specimens have been forwarded to fifty-one different naturalists and institutions. A list of these is also appended.

Recently a new department has been added to the station. Through this naturalists will be enabled to obtain mounted specimens of microscopic animals, viz., sections of embryos of all kinds of fishes, \&c., preparations of larvæ or 'other animals too small for being sent in alcohol or other preservative solutions. Next year a catalogue of these specimens will be published, and the station will be prepared to send the specimens to any naturalist requiring them.

Trials of diving by means of the new Scaphander apparatus have also recently been made with very satisfactory results.

The aquarium of the station is being in part reconstructed, with some important new features, viz., moveable rockwork, for saving and examining the different animals which thrive by themselves on these rocks. This will enable statistical notes to be established on the growth of these animals, and on such changes as may occur by changing their habitat, inasmuch as these rocks may be replaced in the sea at different depths.

The following monographs are in preparation by workers in the station:-Ctenophoræ, Fierafer, Balanoglossus, Sipunculoidæ, Capitellidæ, Planariæ, Nemertineæ, Pycnogonidæ, Caprillidæ, and on several families of Algæ.

Three parts of the "Mittheilungen aus der zoologischen Sta" tion zu Neape], zugleich ein Repertorium für Mittelmeerkunde" have been published, containing sixteen papers illustrated with many very carefully executed plates. Further parts are in active preparation.

It is, moreover, intended to publish the following works :-

"Fauna und Flora des Golfes von Neapel und der angren- 